\title{
Green banking: A strategic response to environmental turbulence
}

\author{
Saurabh Grover ${ }^{1}$, Hardeep Kaur ${ }^{2 *}$ \\ ${ }^{1,2}$ Assistant Professor, Dept. of Commerce and Management, Khalsa College for Women, Amritsar, Punjab, India
}

*Corresponding Author: Hardeep Kaur

Email: shilpim31@yahoo.co.in

\begin{abstract}
Enterprises have become increasingly interested in forming and implementing strategies to feel the effects of environmental issues that impact their competitive landscape in ways not envisaged earlier. Every sector of the society is adopting a green approach in lieu of achieving economic, social, and environmental performance along with the attainment of sustainable development. Green banking is a dynamical method of enhancing environmental quality and conserving energy. It provides the market-based solution for combating a wide range of environmental problems ranging from climate change, deforestation, and water conservation to preservation of biodiversity. Banks being the major financer are implementing practices and guidelines to reduce the global carbon emission. This paper discusses the green banking practices adopted by various Indian banks in response to environmental turbulence.
\end{abstract}

Keywords: Green banking, Energy conservation, Environment protection, Deforestation, Biodiversity and sustainable development.

\section{Introduction}

With increasing attention towards environmental turbulence, climate change is the most convoluted issue the world is facing (Jain, 2013). Across the globe, there have been incessant endeavors to quantify and alleviate the risk of climate change caused by human activities. Many enterprises are actively integrating sustainability principles into their business (Charles, Swapna, Venkadesh 2013). The outlook of society, towards the environment has been changed. A bank that influences the economic growth and development in terms of both quality and quantity are also incorporating Green Banking strategies in their operations. Although banks are considered to be environment-friendly but a pragmatic contribution to sustainable development can be achieved if they operate within an appropriate framework that accounts for cost-efficient policies and economic efficiency (Sahoo \& Nayak, 2007). Thus, banks need to play a proactive role in incrementing government efforts towards sustainability by adopting technology, process and products that build the post-carbon economy i.e. they should harness green banking (Biswas, 2011).

Green banking is a dynamical method of enhancing environmental quality and conserving energy. This concept persuade banks to conduct their operations measuring the social and environmental impacts of its activities (Jha and Bhoome, 2013; Biswas, 2011). Institute for Development and Research in Banking Technology defines Green Banking as an umbrella term that contains policies and procedures that enhances the sustainability of banks in economic, ecological and social dimensions. This concept of "Green Banking" will enhance the asset quality of the banks in future (Assessment, 2005).

Green banking persuades customers to change their habits in lieu of banking sector with an aim of growing consumer interest in environmentally-friendly goods and services. According to Indian Bank Association 2014, "Green banking encompasses all the social and ecological factors so as to protect the environment and conserve of natural resources." The concept of Green Banking came from
Triodos bank established in 1980 (from Dutch origin) with the focus on environmental sustainability in the banking sector from the very first day (Dash, 2008). According to RBI (IDRBT, 2013), green banking focuses on developing eco-friendly internal bank operations, physical infrastructure and Information Technology. Some of the banks as a part of their corporate social responsibility have also instigated 'Green fund' initiative in the year 1990 for funding ecofriendly projects especially. Seeking this example, the banks around the world has started taking green initiatives in the banking sector.

\section{Review of Literature}

Jha \& Bhome (2013) examined the green banking initiatives taken by the public sector bank in India. They also measured the awareness of customers, employees and other stakeholders about the green banking concept. Further, the study suggested that interest on loan should be less for a green project then the normal rate of interest and companies can increase their profitability by recycling of waste generated. They should stress upon green mortgage loan, green credit card and online banking.

Jaggi (2014) conducted a comparative analysis of green banking initiatives taken by SBI and ICICI bank. He also focused on opportunities and threats of green banking in India.

Khedekar (2014) studied the eco-friendly technologies opted by different banks. According to study bank should provide basic premium internet banking product such as opening bank account, Demat holding, standing instruction, investment etc. This study suggested that the bank should conduct a seminar and conference to educate the public regarding the uses of internet banking as well as a security issue.

Nath Nayak \& Goel (2014) examined the eco-friendly initiatives taken by the top four nationalised and private sector banks in India. They found that in order to penetrate into global economy, Indian banks must be acquainted with their responsibilities as a global corporate citizen. 
Ritu (2014) focused on the necessity to raise awareness about the green banking products and methods among the employees as well as customers. She highlighted various green banking practices that can be followed by the banks to make our environment human-friendly. She also discussed about the benefits and weaknesses of green banking.

Bihari \& Pandey (2015) studied the steps undertaken by the Indian public and private sector banks for the sustainable banking. The study discussed about the paperless banking strategies adopted by the banks. It was concluded that the banks are opting different tactics to enhance their image under the concept of green banking.

\section{Objectives of the Study}

1. To understand the strategies adopted by Indian commercial banks to go green.

2. To understand various initiatives taken toward green banking by commercial banks in India.

\section{Strategies for Green Banking Approach}

The latest developments in Indian banking technology has profoundly transformed traditional banking. The modern banking serves the interests of customers, businesses and the environment. Nowadays, banking operations are omnichannel that allow customers to carry out their transactions through variety of banking channels such as Internet banking, mobile banking, Green Channel Counters, kiosk banking, use of smart cards, etc. The GOI has issued a guideline for all the public sector banks and RRBs to apply the following green initiatives:

1. Focus towards the use of Electronic Payment.

2. Use of Core Banking Solution (CBS).

3. Use of Video Conferencing.

4. Offer a centralized payment system

The implementation of social and environmental approaches by the banks will facilitate them in achieving an efficient environmental management system. However, the following strategies can be implemented to reduce the carbon footprint of individual banks:

\section{Going Online}

Online Banking offers the facilities like paying bills online, making remote deposit, online fund transfers etc. such paperless transactions facilitate energy conservation and preserve natural resources. Customers get an option to save money by avoiding late payment of fees. An online transaction offers convenience in terms of time and place. These are also highly effective ways to keep track of your finances and to avoid late payment of fees.

\section{Carbon Credit Business}

Under the Kyoto protocol, all nations must adopt Clean Development Mechanism (CDM) projects to reduce greenhouse gases emission. The banks can conduct carbon credit business, thereby providing all the services in the area of CDMs and carbon credits. The services like identification and funding of CDM projects, advisory services and commercialization of such projects help to meet the requirements of its customers and other related banking services.

\section{Using Green Checking Accounts}

Customers must be persuaded to use ATM or special touch screens in the banks for passbook updation, generation of statement, deposit or withdrawal of money etc.

\section{Green Credit Cards}

Banks can introduce Green Credit Card schemes. These cards act as a platform that offers a variety of monetary rewards for a worthwhile cause of environment protection. Green Cards sustain the planet as they are bio-degradable and enable communication on recycled material. They can be used for online purchasing, producing E-statements and various other purposes.

\section{Green Mortgages}

The Ministry of Renewable Resources in collaboration with some public sector banks has made various to save environment. One of the initiatives is to give low-interest loans to customers interested in eco-friendly projects like purchasing solar equipment, erecting the bio-gas plant etc. For example, SBI provides Green Home Loan Scheme to customers for environment-friendly residential projects.

\section{Green Banking Financial Products}

The banks can set up a 'Green Fund' to provide climateconscious customers with the option of investing in environmentally friendly projects. While financing any project, they can opt for an Environmental Impact Assessment in their project appraisal also. It would help to measure the nature and magnitude of environmental impact as well as recommend environmental risk mitigation measures (Dash, 2008).

\section{Carbon Footprint Reduction}

Carbon foot-print is a measure of the impact of our activities on the environment. It relates to the amount of green house gases emitted during daily business operations. (Kanchan and Kumar, 2005). However, following steps can be taken by the banks to reduce their carbon footprints:

1. Paper-less Banking: With the computerization of bank branches, there is ample scope for doing paperless banking. The public sector banks squander a lot of money on enormous quantities of paper being used for office correspondence, audit reporting, recording public transactions, etc. These banks can opt for electronic correspondence and reporting (Dash, 2008). They should motivate their customers also to go for electronic transactions and ensures their security and integrity at the same time.

2. Power Saving Equipment: Energy audits can be conducted in the banks to motivate them to switch over to renewable energy (solar, wind, etc.) to manage their offices and ATMs. It would facilitate effective energy management.

3. Using Mass Transportation System: One single transport can be used for a group of officials working in one branch. A common transportation system would enable banks to become fuel efficient organizations.

4. Green Buildings: The banks should construct use green buildings for their offices and employee accommodation. 


\section{Social Responsibility Services}

Under green banking initiatives, Indian banks can pursue various social responsibility services such as tree plantation camps, maintenance of parks, pollution check-up camps, etc.

\section{Initiatives by Commercial Banks in India State Bank of India}

SBI installed around ten windmills with an aggregate capacity of $15 \mathrm{MW}$ in the states of Tamil Nadu, Maharashtra and Gujarat. It was their first successful venture into the generation of green power. The bank has also initiated 'Green Channel Counter' facility. It was the step to go paperless. The motive was to persuade customers to opt for 'Green Banking' instead of using pay-in-slips for deposit, withdrawal and remittance transactions. The bank provides concessional interest rates for renewable energy projects and has made separate agreements with Multilateral/Bilateral Agencies for lines of credit for launching Rooftop Solar and other projects in the renewable energy space. The bank has given a commitment to Govt. of India to finance viable renewable energy projects worth Rs 81,600 crore over the five year period (2015-2020). SBI is a first public sector signatory to the Carbon Disclosure Project (CDP) and has been reporting there under since 2012.

\section{Punjab National Bank}

PNB initiated Green E-Vigilance. This strategy allows banks to handle customer grievances through e- network. The bank has also undertaken various other activities under green initiatives such as using solar powered ATM, use of power saving equipments, rainwater harvesting for water conservation, first preference towards going paperless but only under urgent circumstances- printing on both sides of the paper etc. Further, the bank favours environmentfriendly projects like installation of windmills and solar power projects during credit appraisal. In addition to this, the bank itself has undertaken several eco-friendly projects like energy audit of all offices, installation of Solar UPS at selected ATM sites in Bihar and U.P, setting up of green lobby, installation of Cash Deposit Machine, Passbook Updation Machine and Cheque Deposit Machine powered by solar energy. Bank has also set up a butterfly park in the complex of the Guruvayur temple containing 18 types of medicinal plants.

\section{Bank of Baroda}

In lieu of energy conservation, the initiatives undertaken by the bank include real-time monitoring of temperature and pressure, energy efficient IT equipment selection, solar powered UPS etc. With an aim of going paperless, they have registered the e-mail ids of their stakeholders for any kind of correspondence. This bank does not finance any project which it found detrimental to environment rather it preferential treatment for eco-friendly green projects The bank has also executed Lending Automation Processing System (LAPS) system for appraisal of Retail \& SME loans. They have also built their first green building at Varanasi followed by next construction in Jaipur as per the standards of Indian Green Building Council (IGBC). The entire lighting is provided through an installation of the Solar Power Generation System (SPGS).

\section{IndusInd Bank Ltd}

The bank has started campaign named 'Hum aur Hariyali'. This was the first bank to install solar-powered ATM in Mumbai that actually saves $1980 \mathrm{kWh}$ of energy annually. The Bank is also working in the areas of Water Stewardship, forest management, waste management and other ecofriendly finance programs and projects.

\section{ICICI Bank}

ICICI Bank launched 'Go Green' - an organisation-wide initiative to reduce its own carbon footprint. To build a greener future, the bank has started sending e-statements and e-greetings to its customers. It funded a range of ecofriendly projects across the country to restore ecological balance. The bank also motivate its employees to contribute towards green initiatives that range from Green offerings, Green engagement to Green communication.

\section{Axis Bank}

The recycling initiative of Axis bank under the Green Banking banner has helped the bank use around 21,572 kilograms of dry waste productively. The bank has invested in solar energy for clean energy generation and reduction in carbon footprint. Some of the key energy management initiatives undertaken are:

1. Renewable energy - they have installed a total of 3 MW of solar energy systems which translates to an annualised estimated low carbon energy generation of 4,136 Mwh during the year and a reduction in emissions of 3,294 tCO2e.

2. Smart energy control systems - More than 500 branches are now installed with a remote-managed smart energy control system. This system allows central monitoring of the office energy consumption on a realtime basis. Thus, it offers the benefit of improving energy efficiency proactively.

3. LED lighting - CFL lights are replaced with LED lights at Axis House. On an annualised basis, this has a potential of 76 Mwh of energy savings leading to 62.52 tCO2e emissions reduction.

4. Efficient HVAC systems - HVAC system in Axis House was optimised and retrofit of Air Handling Unit (AHU) at NPC II was done. This has a potential of annualised energy savings of $649 \mathrm{Mwh}$ resulting in a reduction in emissions of carbon dioxide.

\section{HDFC Bank}

This was the first bank to bank to install rechargeable Lithium -Ion batteries for uninterrupted power supply in their ATMs. They also introduced server and desktop virtualization for reducing power consumption. Banks favour the use of electronic media in comparison to print media with a motive of encouraging retail customers to subscribe to paperless transactions. To reduce environmental footprint, the bank is continuously upgrading itself with innovative ideas. The bank has initiated Energy Management Kits in branches such as the use of star-rated and energy-efficient air-conditioners, switching off the 
branch signage after $11 \mathrm{pm}$, etc. The focus is also towards the raising of employee awareness by promoting environment-friendly practices, arranging motion sensors to switch off lights in an empty room etc.

Thus, both public and private sector banks are complying with their social responsibility by initiating various Go Green measures to convert their accounting principles from purely being 'monetary economics' to 'ecological economics'.

\section{Conclusion}

Green is the word now. All over the world, banks and financial institutions are worried about the exhaustion of the environment. Though there is a constant increase in awareness for conserving and protecting the environment, Indian banks still require passionate involvement, dedication and commitment from all the stakeholders like Government, Financial institutions, banks, regulators, corporate and community at large. If they desire to enter global markets, they should incorporate ecological and social guidelines to which banks worldwide are agreeing to. A fundamental change is required to set up the banking operations that consider 3 Ps- the people, the planet and the profit. Implementing Green excellence awards and recognitions, Green rating agencies, Green investment funds, Green insurance and Green accounting would enable eco-friendly business practices which would benefit our future generations.

\section{Conflict of Interest: None.}

\section{References}

1. Ahuja, N. (2015). Green banking in India: A review of literature. Int J Res Managt Pharm 2015;4(1):11-6.

2. Assessment, M. E. (2005). Ecosystems and human well-being: Our human planet: Summary for decision makers. Island press.

3. Axis Bank. (2010 to 2018). Annual Report. Axis Bank.

4. Bahl S. Green banking-The new strategic imperative. Asian J Res Business Econ Manag 2012;2(2):176-85.

5. Bahl S. The role of green banking in sustainable growth. Int $J$ Marketing, Financial Serv Manag Res 2012;1(2):27-35.

6. Barhate G. H., \& Tamboli M. A. Green Banking: An Overview. IBMRD's J Manag Res 2016;5(2):49-52.

7. Bank of Baroda. (2010 to 2018). Annual Report. Bank of Baroda.

8. Belz F. M., \& Peattie, K. Sustainability marketing: A global perspective.

9. Bihari S. C. Green Banking-Socially Responsible Banking in India. The India Banker, 2011;6(1).

10. Bihari S. C., \& Pandey B. Green banking in India. J Econ Int Finance 2015;7(1):1-17.

11. Biswas N. Sustainable green banking approach: The need of the hour. Business Spectr 2011;1(1):32-8.

12. Bhardwaj, B. R., \& Malhotra, A. Green banking strategies: sustainability through corporate entrepreneurship. Greener $J$ Business Manag Stud 2013;3(4):180-93.

13. Charles S., Swapna D., \& Venkadesh S. Marketing Strategies towards Sustainable Buildings. Int J Logist Supply Chain Manag Perspect, 2013;2(1):83.
14. Chaurasia A. K. Green banking practices in Indian banks. $J$ Manag Soc Sci 2014;1(1):41-54.

15. Dash, R. N. (2008). Sustainable 'Green'Banking: the story of triodos bank. Cab Calling, 2008;5:26.

16. Dharwal, M., \& Agarwal, A. (2013). Green banking: An innovative initiative for sustainable development. ACCMAN Institute of Management Article, 2(3), 1-7.

17. Garg, S. (2015). Green Banking: An Overview. Glob J Adv Res 2015;2(8):1291-6.

18. Gosavi, Y. M. Green Marketing-Opportunities \& Challenges. Met Management Retrospect, 22.

19. HDFC Bank. (2010 to 201*). Annual Report. Housing Development Finance Corporation Bank.

20. ICICI Bank. (2010 to 2018). Annual Report. Industrial Credit and Investment Corporation

21. Jaggi, G. (2014). Green Banking: Initiatives by SBI and ICICI. Paripex-Indian J Res 2014;3(6).

22. Jain N. Green Banking: A Ground Breaking Initiative for Sustainable Development. Int J Logist Supply Chain Manag Perspect 2013;2(1):166.

23. Jha N., \& Bhome, S. A study of green banking trends in India. Int Mon Referred J Res Manag Technol 2013;2:127-32.

24. Kandavel D. Green Banking Initiatives of the Commercial Banks in India. SIT J Manag 2013;3(2):213-25.

25. Kiran, K. U. Opportunity and Challenges of Green Marketing with special references to Pune. Int J Manag Soc Sci Res 2012;1(1):2319-4421.

26. Khedekar P. Banking with Technology: Green Banking. Renewable Res J, 2014;3(1):167-71.

27. Lalon R. M. (2015). Green banking: Going green. Int J Econ, Finance Manag Sci, 2015;3(1):34-42.

28. Masukujjaman, M., \& Aktar, S. Green banking in Bangladesh: A commitment towards the global initiatives. J Business Technol (Dhaka), 2013;8(1-2):17-40

29. Nath V., Nayak N., \& Goel A. Green banking practices-A review. IMPACT. Int J Res Business Manag (IMPACT: IJRBM) 2014;2:45-62.

30. Punjab National Bank. (2010 to 2015). Anuual Report. Punjab National Bank.

31. Rahman A. (2013). Green banking and sustainable development: the case of Bangladesh. The Bangladesh Accountant.

32. Ritu. Green Banking: Opportunities and Challenges. Int $J$ Informative Futuristic Res (IJSER) 2014;2(1)ISSN (Online): 2347-1697

33. Sahitya U., \& Lalwani V. (2014). Sustainability in Indian Banking Industry. IRACST, Int J Commerce, Business Manag (IJCBM), ISSN, 2319-2828.

34. State Bank of India. (2010 to 2017). Annual Report. State Bank of India.

35. Sahoo, P., \& Nayak, B. P. (2007). Green banking in India. Indian Econ J, 2007;55(3):82-98.

36. Sarohi, Y. Green Human Resource Management: Comparison of Green Initiatives by Public and Private Sector Banks in India.

37. Tiwari J. Green marketing in India: An Overview. IOSR J Business Manag 2014;1:33-40.

38. Yadav R., \& Pathak G. Environmental sustainability through green banking: A study on private and public sector banks in India. OIDA Int J Sustainable Dev 2013;6(08):37-48.

How to cite this article: Grover S, Kaur H. Green banking: A strategic response to environmental turbulence. J Manag Res Anal 2019;6(2):120-3. 